\title{
Molecular docking studies of BCL- 2 with Erythroxylum monogynum Roxb. compounds for anti inflammatory studies
}

\author{
C. Dhanunjaya Kumar ${ }^{1}$, S. Nasireen Begum ${ }^{2}$, D. Muralidhara Rao ${ }^{3 *}$ \\ ${ }^{1}$ Department of Biotechnology, Sri Krishnadevaraya University, Anantapuramu, India \\ ${ }^{2}$ Department of Biotechnology, JNTUA, Anantapuramu, India \\ ${ }^{3}$ Department of Biotechnology, Sri Krishnadevaraya University, Anantapuramu, India \\ Corresponding Author: dhanuscience333@gmail.com Te: 9491848336
}

Available online at: www.isroset.org

Received: 16/May/2019, Accepted: 17/Jun/2019, Online: 30/Jun/2019

\begin{abstract}
Due to the presence of large number of phyto compounds the medicinal plants shows wide spread properties for diseases which are not cured by traditional medicine. In this work bioactive compounds of Erythroxylum monogynum plant extracts were selected .By the studies of Gas chromatography and mass spectrum the compounds present in Erythroxylum monogynum ethanolic extracts were identified based on retention time , area. The compounds which were identified are used for anti inflammatory activity by insilico method with BCL-2 which plays key role in causing of inflammation. Hence this is selected for docking studies with the different compounds of Erythroxylum monogynum .The docking results showed that among compounds of Erythroxylum monogynum compounds the Cyclo Hexane, 2-Ethoxy

-1-hydroxy-4-oxo-3-phntyl-32cyclobutenyl)acetate, $\quad$ 1,8-bis[(benzoyl)benzoyloxy]-3, $\quad$ 6-dioxa $\quad$-octane, $\mathrm{N}$ (Tetramethylpiperidinyl) ortho-fomyl benzoate , 1,30-Triacontanediol ,5-trichloro methyl-3-[1-(cyanothio)ethyl]-4, 5dihydroisoxazol-5-ol.
\end{abstract}

Key words : Erythroxylum monogynum, Anti-inflammatory, Phyto compounds, BCL-2, Docking studies

\section{INTRODUCTION}

Inflammation is a result of harmful stimuli and is a complex biological phenomena which is caused by so many reasons and some are due to damaged cells ,pathogens[1].Due to generic response it is said be process of innate immunity type when compared with adaptive immunity which is particular for a specific pathogen[2] However, it may be chronic in case of uncontrolled acute inflammation which is responsible for various inflammatory diseases [3]. The inflammation is characterized by mainly five different properties redness, swelling, heat, pain, and loss of tissue function, this is mainly due to any injury or bites on insects or animals[4]. Chronic pain, decreased quality of life, poor sleep quality are some of results due to chronic inflammation[5]It may also works as a precursor to various cancers and the persistent inflammation is associated with damage of DNA which automatically leads to cancer [6]. The rate of increasing of various illnesses suggest that chronic inflammation, caused by non appropriative and and severe inflammatory activity, [7],[8],[9] .The decrease in chronic inflammation also reduces the vascular diseases[10] Today one of the global health problem is inflammation ,this causes both economic and psychological challenges. The challange of inflammation cure and prevention is the great task for global scientific community .On various studies of inflammation by the epidemiological studies which involves different parameters like age ,sex ,geographical location ,migrating populations showed that the way of living is main cause for inflammation causing factor [ 11],[12],[13]. Automobile pollution ,occupational carcinogens in working areas, mutagens, microbial infections, radiations of solar UV and genetic suspetibity are other factors [14],[15] .The modifiable risk factors like diet intake, smoking, consumption of alcohol ,body mass and body exercises in routine life. The reducing factors inflammation are life style change ,doing exercises, avoiding of alcohol \& smoking, anti obesity, intake of low products of fat . These modifications reduce inflammations especially for colorectal and breast.According to the guidelines laid by American inflammation society and nutrition diet, some studies showed that intake \& not less five fruits and vegetables, less intake of red meat, sugars, sweets, refine grains gives good results. The guidelines for early diagnosing for finding of detection of inflammations of certain regions recommended. [16]. The risk of inflammation by dietary habits was given by epidemiological 
data. The scientific community started generations of various diets to reduce inflammation especially involving of vegetables and fruits (17],[18], [19],[20].

In general the fruits and vegetables contains large number of phyto compounds. These compounds shows different chemical structures and properties. Usually they are studied by a number of researchers for their anti inflammatory properties .As these anti-inflammatory products are plant origin (naturally available) the side effects are very less or absent. These compounds also contains vitamins, fiber, minerals which are key components for good health. In general these compounds contains less fats. The present work deals with the molecular docking studies BCL-2 gene with the various compounds of leaf extracts of Erythroxylum monogynum for the anti inflammation.

\section{METHODOLOGY}

\section{Identification of compounds by GC - MS method:}

By using Gas Chromatography CLARUS 550 Perkin Elmer system the GC - MS analysis are carried out. This consists of a gas chromatograph interfaced to a MS(Mass Spectrometer) with the following conditions. The column Elite -1 fused silica capillary column $[30 \times 0.25 \mathrm{~mm}$ ID $\times$ IEM df, which is compared $100 \%$ dimethyl poly siloxane], operating in an electron impact mode at 70ev; The helium (99.999\%). was used as carrier gas at a constant flow of $1 \mathrm{ml} / \mathrm{min}$ and an injection volume of $0.5 \mathrm{EI}$ was employed with split ratio of $10: 1$ injector temperature $250^{\circ} \mathrm{C}$; ion-source temperature $280^{\circ} \mathrm{C}$. The oven temperature was fixed from $110^{\circ} \mathrm{C}$ (isothermal for $2 \mathrm{~min}$ ), with an increase of $10^{\circ} \mathrm{C} / \mathrm{min}$, to $200^{\circ} \mathrm{C}$, then $5^{\circ} \mathrm{C} / \mathrm{min}$ to $280^{\circ} \mathrm{C}$, ending with a 9 min isothermal at $280^{\circ} \mathrm{C}$. Mass spectra were taken at $70 \mathrm{eV}$; a scan interval of $0.5 \mathrm{~s}$ and fragments from 40 to $550 \mathrm{Da}$.

\section{Structure Prediction:}

By using the PDB data base the structure of BCL -2 was obtained. By using DBV software the unnecessary chains and hetero atoms are removed to the protein the hydrogens are added and used for active site prediction.

\section{Active site Identification:}

This is a dependent on methods of computational geometry which includes the discrete flow theory and alpha shape. the pocket mouth opening and pockets are identified by CASTp and measured by CASTp. The atoms lining the benied cavities, pockets, pocket openings are specified by program, the area and volume of cavities and pockets, and the circumference and area of mouth openings .

\section{Docking Method:}

By using Genetic optimization of ligand Docking (GOLD) software the docking was carried out. The Gold software based on GA (Gold Algorithm). The partial and as were as full flexibility of the ligand was allowed in this method. Homo sapiens BCL - 2 active site was docked with the compounds which were identified in GC - MS. By using the calculations Molecular mechanics. The caffeine interaction with active site residues were studied thoroughly. The Genetic algarithm parameters used were population size ,Niche size ,selection pressure , Number of island, Number of operations [10,000] .The migration ,cross over, mutation parameters are set to $10,100,100$. The cutoff default values for hydrogen bonds $3.0 \mathrm{~A}^{\circ}(\mathrm{dH}-\mathrm{x})$ and for Vanderwaals $6 \mathrm{~A}^{\circ}$ were employed. The default algorithm speed was selected during docking and within $10 \mathrm{~A}^{\circ}$ radius. The ligand binding sites are defined in the targets with centroid as CE atom of active residues. The number of poses was set to 100 for each inhibitor and the early termination was allowed for a ligand which was top three bound conformations were within $1.5 \mathrm{~A}^{\circ} \mathrm{RMSD}$.

The poses of individual binding compounds were observed after docking and their proteins interaction were studied. The highest energetically favourable conformation possessing, best ligand was selected

\section{Gold Score Fitness Function:}

The Gold Score operates a force field depended scoring function and is composed of four components:

1. The hydrogen bond energy of protein - ligand ( $\mathrm{H}$ - bond external ).

2. The Vander waals energy of protein ligand (external volume).

3. The internal Vander waals energy of ligand (internal volume).

4. The intra molecular hydrogen bonds energy of ligand (the internal $\mathrm{H}$ bond).

By the factor of 1.375 the external volume score was multiplied when computed the total fitness score. In order to enhance the protein ligand hydrophobic contact this is an empirical correction. In order to predict the binding positions of ligands the fitness function optimized.

GoldScore is enoted as $\mathrm{S}\left(\mathrm{hb} \_\right.$ext $)+\mathrm{S}\left(\mathrm{vdw} \_\right.$ext $)+\mathrm{S}$ (hb_int $)+\mathrm{S}$ ( vdw_int) 
Where the $\mathrm{S}$ (hb_ext) is the bond score of protein-ligand hydrogen,

$\mathrm{S}$ (vdw_ext) indicates score of the protein-ligand van der Waals ,

$\mathrm{S}$ (hb_int) indicates the score from intramolecular hydrogen bond present in the ligand and

$\mathrm{S}$ (vdw_int) ndicates the score of intramolecular strain present in the ligand

\section{RESULT AND DISCUSSION}

Erythroxylum monogynum, ethanolic extract compounds were identify by gas chromatography method.The PDB files were collected from the PDB data bank and the BCL -2 stable structure of Homo sapiens obtained is shown in figure 1.In crystal structure the ligand present were removed along with hetero atoms for docking studies.

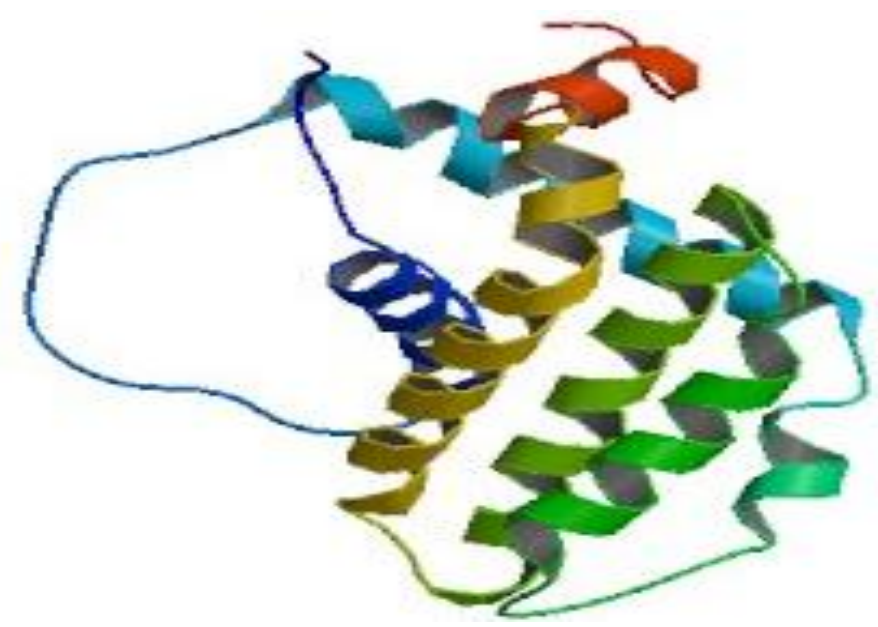

Figure 1 : Structure of BCL2

\section{Active site indentification:}

The BCL - 2 possible binding site was searched after the final modes was built. The searching was based on template structural comparison, constructed model, CASTp server as shown in fig. From the BCL -2 final refined Model with SPDBV program the secondary structure are found to be highly conserved and the residues are shown below.
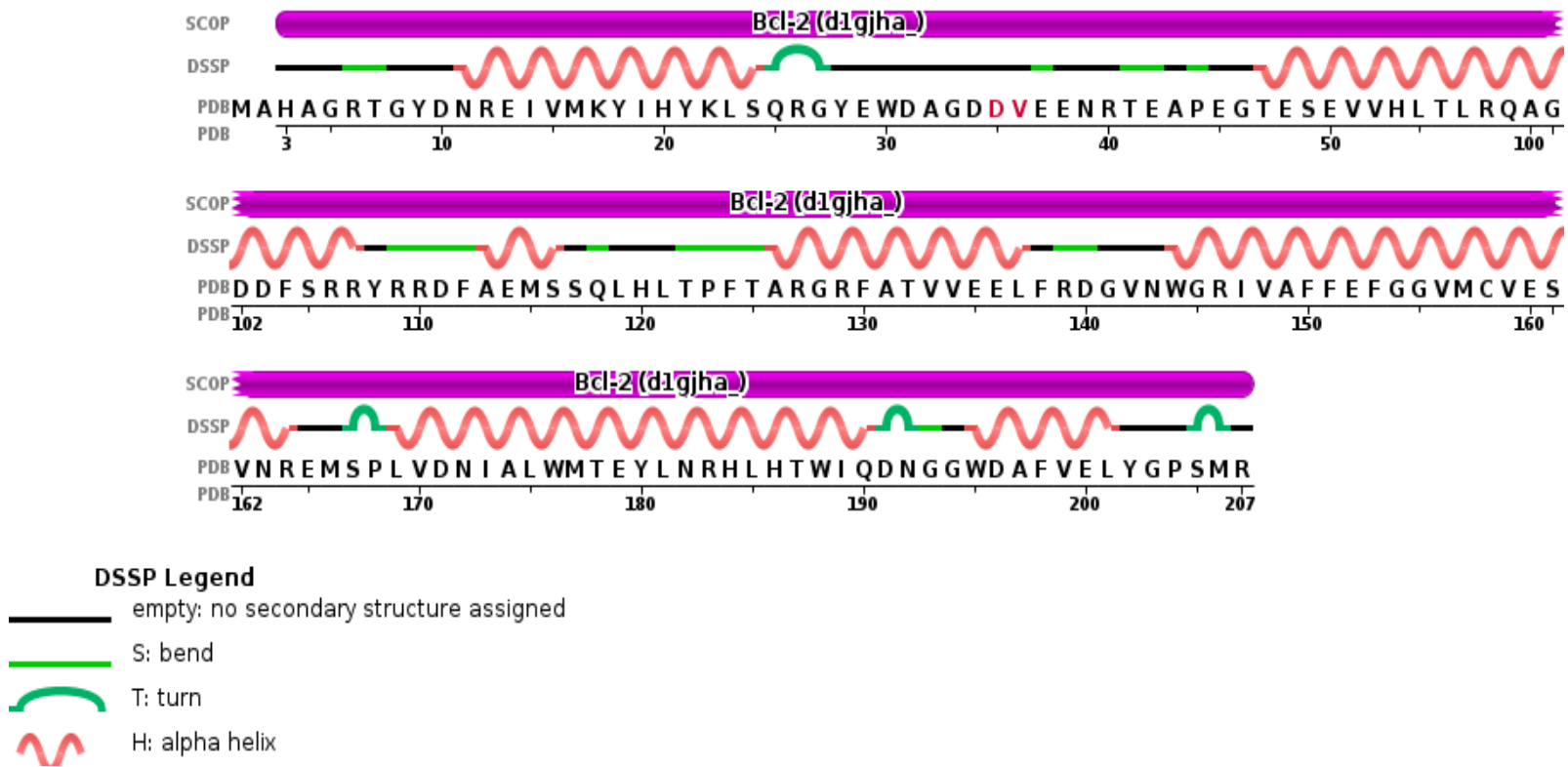

Figure 2: The possible binding sites of $\mathrm{BCL}-2$ 
Table 1: Docking results of the certain compounds

\begin{tabular}{|c|c|c|c|c|}
\hline Fitness & S(hb_ext) & S(vdw_ext) & S(hb_int) & S(int) \\
\hline-1.40 & 5.62 & 13.86 & 0.00 & -26.07 \\
\hline-0.05 & 0.00 & 18.24 & 0.00 & -25.13 \\
\hline 12.21 & 5.96 & 15.47 & 0.00 & -15.03 \\
\hline-10.17 & 0.00 & 11.01 & 0.00 & -25.32 \\
\hline 10.16 & 2.18 & 16.18 & 0.00 & -14.27 \\
\hline-27.56 & 7.44 & 10.16 & 0.00 & -48.97 \\
\hline 8.60 & 6.00 & 18.02 & 0.00 & -22.19 \\
\hline 0.02 & 0.00 & 13.99 & 0.00 & -19.21 \\
\hline 4.32 & 0.00 & 9.41 & 0.00 & -8.62 \\
\hline-12.33 & 12.00 & 16.27 & 0.00 & -46.70 \\
\hline-2.29 & 8.08 & 17.26 & 0.00 & -34.10 \\
\hline-21.65 & 6.00 & 15.74 & 0.00 & -49.29 \\
\hline 10.96 & 6.16 & 16.20 & 0.00 & -17.48 \\
\hline-12.77 & 0.00 & 12.79 & 0.00 & -30.35 \\
\hline-77.0 & 0.00 & 6.03 & 0.00 & -85.30 \\
\hline-24.18 & 1.72 & 16.28 & 0.00 & -48.29 \\
\hline-26.57 & 0.00 & 13.93 & 0.00 & -45.73 \\
\hline 24.12 & 6.00 & 16.51 & 0.00 & -4.58 \\
\hline-39.77 & 6.00 & 10.12 & 0.00 & -59.69 \\
\hline 18.01 & 6.00 & 13.83 & 0.00 & -7.01 \\
\hline-5.77 & 6.00 & 13.56 & 0.00 & -30.42 \\
\hline 21.84 & 11.93 & 13.63 & 0.00 & -8.84 \\
\hline-26.31 & 6.85 & 12.67 & 0.00 & -50.57 \\
\hline 11.53 & 6.10 & 16.44 & 0.00 & -17.18 \\
\hline
\end{tabular}


Best docked compounds wth the BCL-2

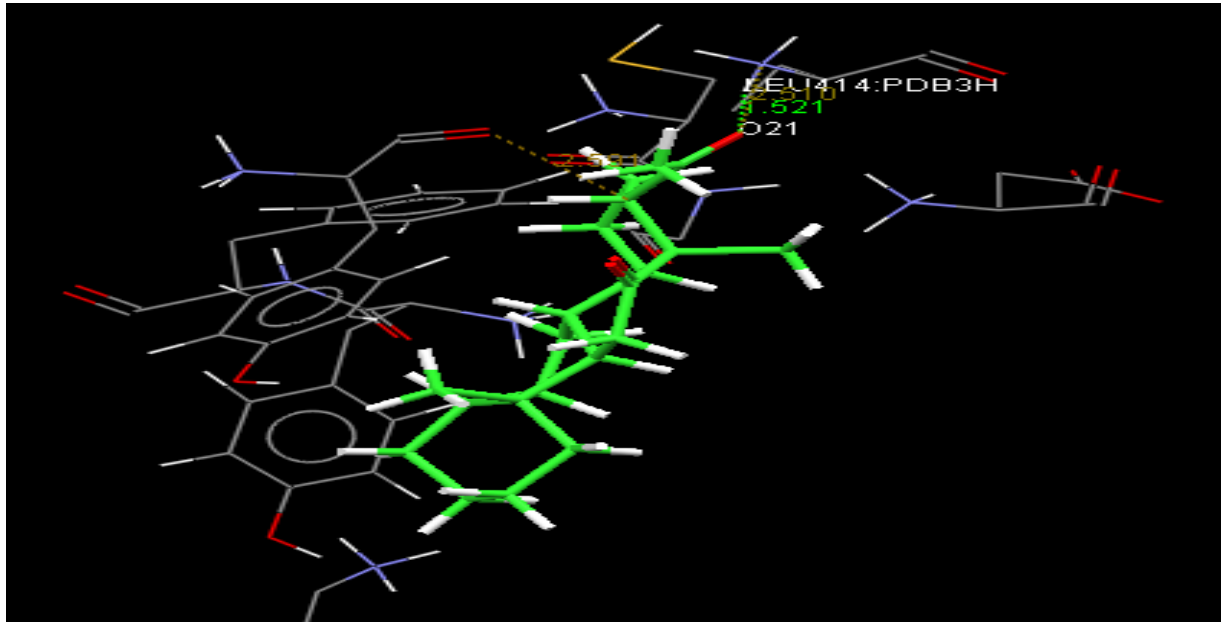

Figure 3: Cyclo Hexane

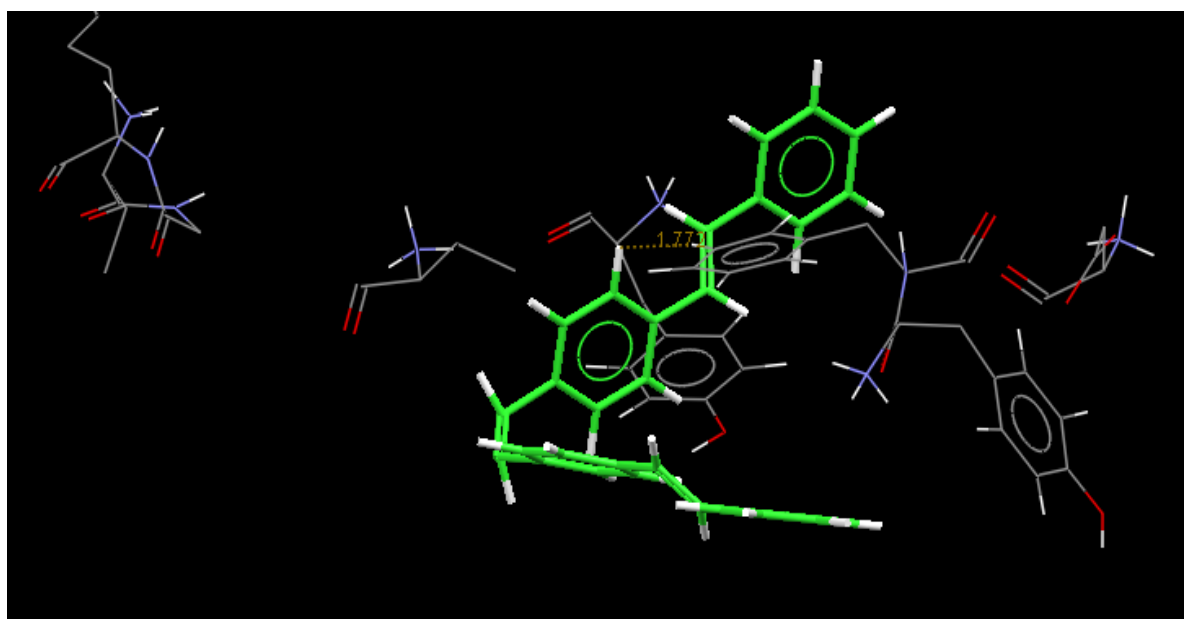

Figure 4 : 2-ethoxy-1-hydroxy-4-oxo-3-phntyl-32cyclobutenyl)acetate

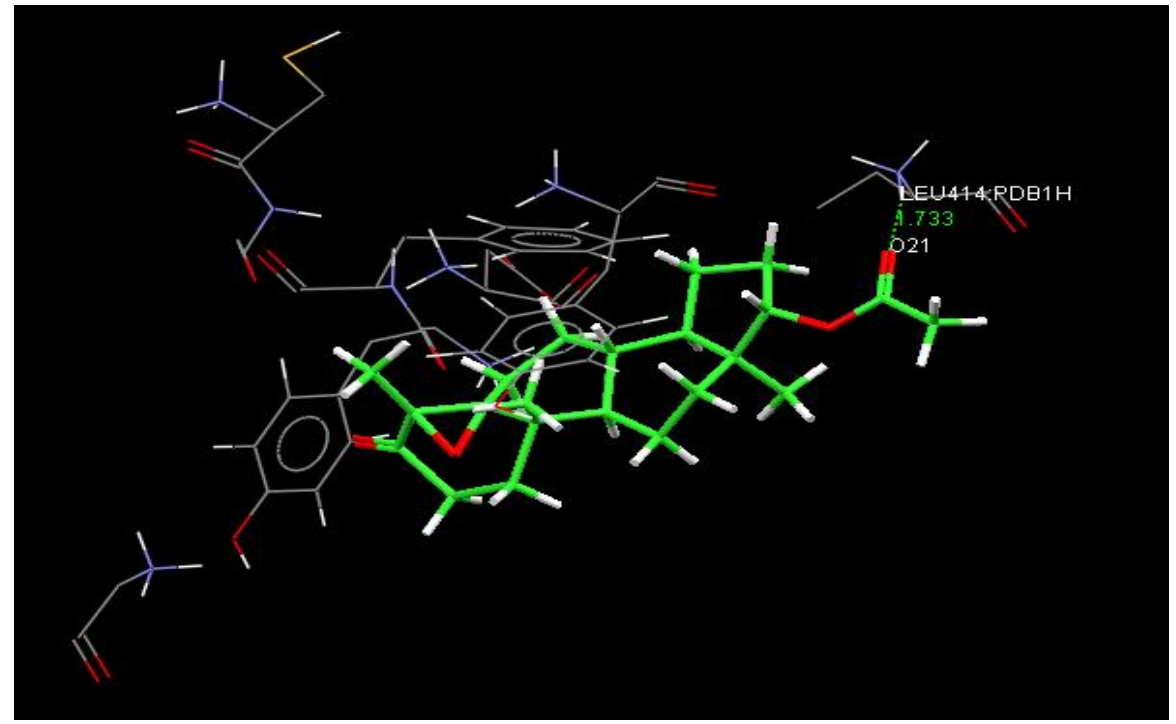

Figure 5: 1,8-bis[(benzoyl)benzoyloxy]-3,6-dioxaoctane 


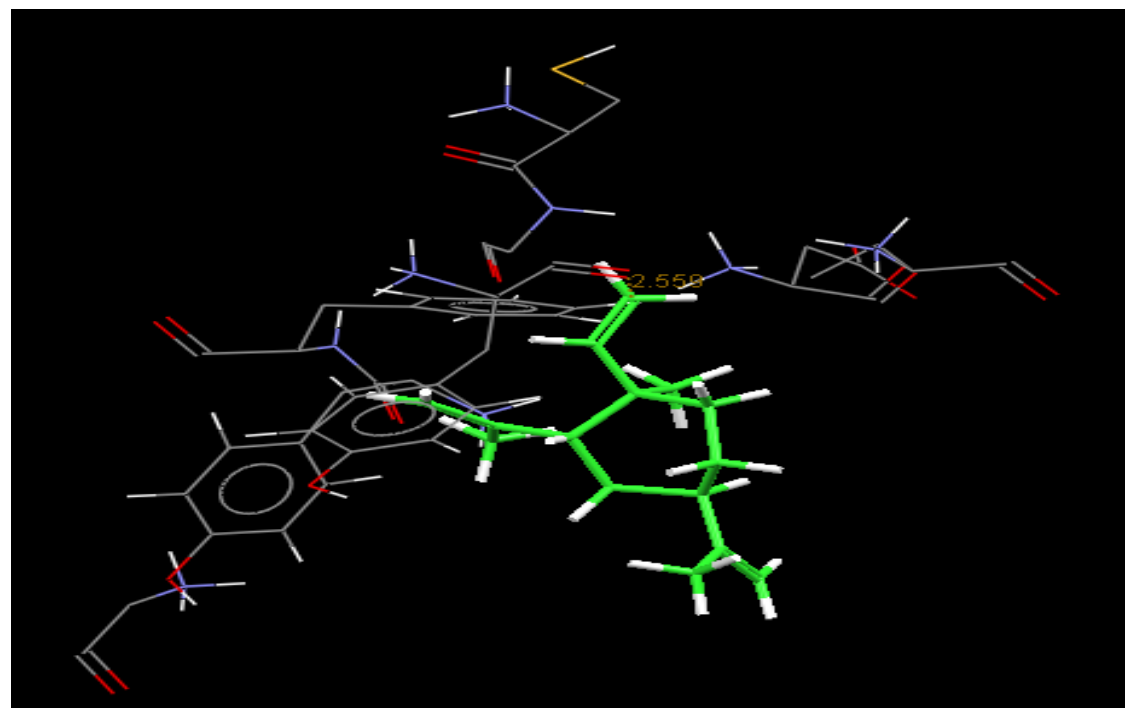

Figure 6 : N- (Tetramethylpiperidinyl) ortho-fomyl benzoate

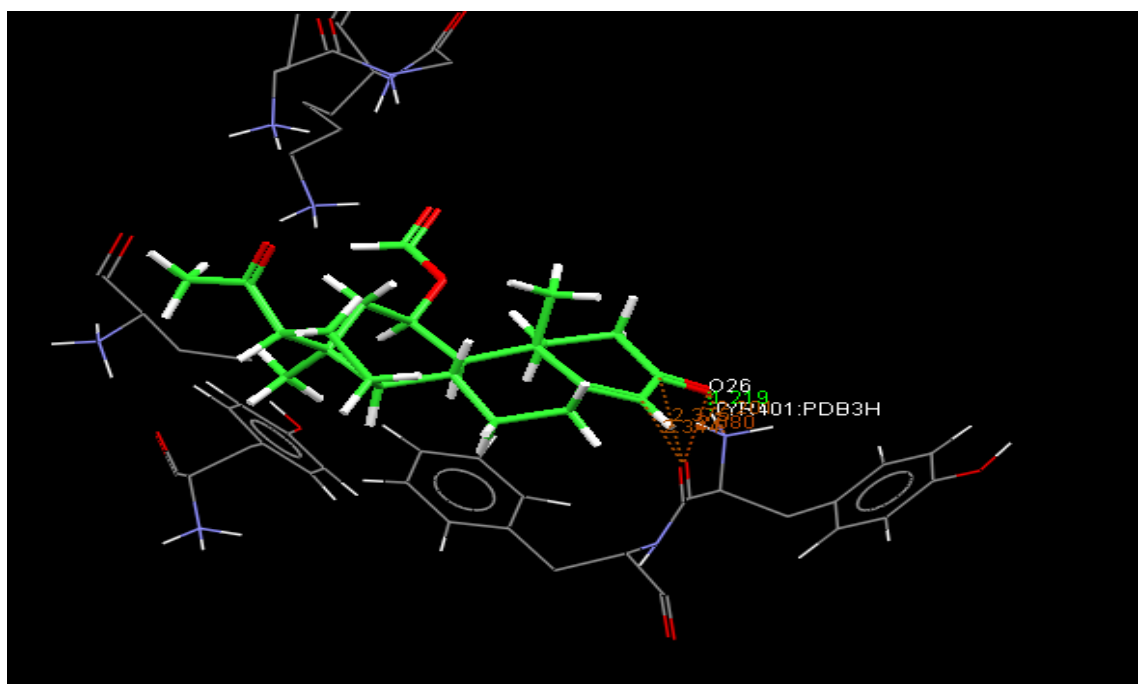

Figure $7:$ 1,30-Triacontanediol

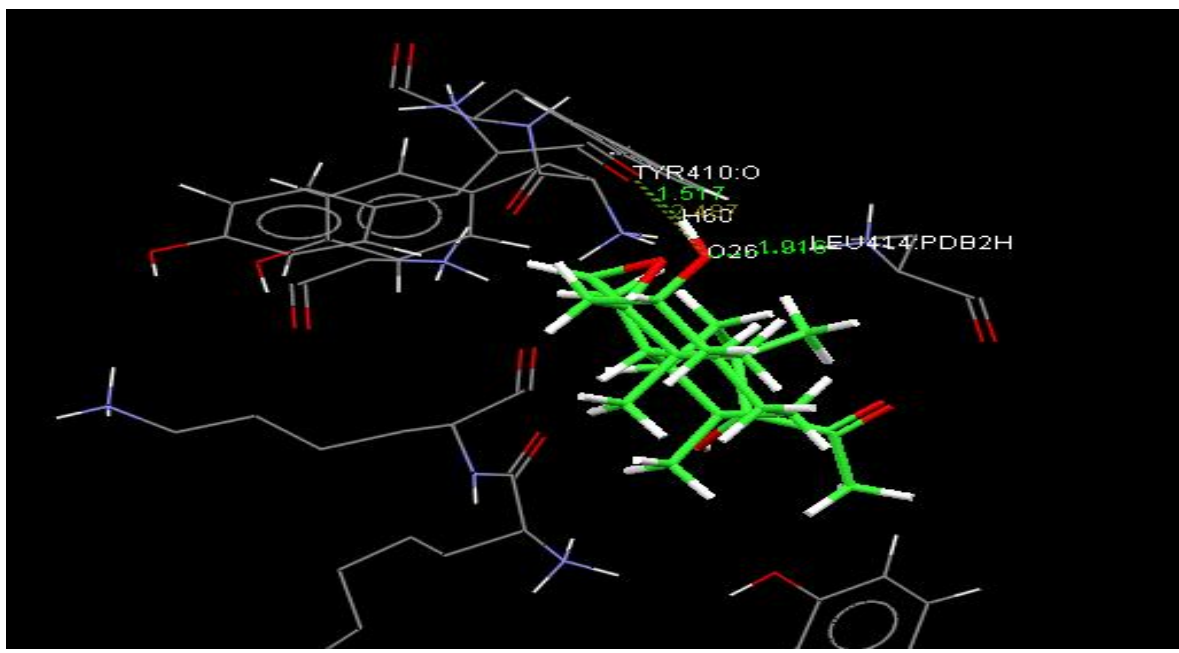

Figure 8 : 5-trichloromethyl-3-[1-(cyanothio)ethyl]-4,5-dihydroisoxazol-5-ol 


\section{IV.CONCLUSION}

The phyto compounds were identified through GC-MS studies and structural conformation was done by Mass Spectrum analysis. The identified phyto compounds were docked for their anti inflammatory activity. Among the phyto compounds the following showed the best docking results with the BCL-2.They are :

Cyclo Hexane,

2-ethoxy-1-hydroxy-4-oxo-3-phntyl-32cyclobutenyl)acetate,

1,8-bis[(benzoyl)benzoyloxy]-3,6-dioxaoctane ,

$\mathrm{N}$ - (Tetramethylpiperidinyl) ortho-fomyl benzoate ,

1,30-Triacontanediol ,

5-trichloromethyl-3-[1-(cyanothio)ethyl]-4,

5-dihydroisoxazol-5-ol

BCL-2 is usually known to cause the inflammation and inhibition of apoptosis.This indicates that this is responsible for the prevention of the natural cell death .So what ever above mentioned compounds well docked with the BCL-2 and stops its functions.

\section{ACKNOWLEDGMENT}

The authors are very much thankful to the Sri Krishnadevaraya University for providing the all necessary laboratory facilities to carry out all essential research work

\section{REFERENCES}

[1] Ferrero-Miliani L, Nielsen OH, Andersen PS, Girardin SE; Nielsen; Andersen ; Girardin February ,2007 .

[2] Abbas A.B.; Lichtman A.H "Ch.2 Innate Immunity". In Saunders (Elsevier) (ed.). Basic Immunology. Functions and disorders of the immune system 3rd edision ,2009.

[3] Zhou Y, Hong Y, Huang H. Triptolide “ Attenuates Inflammatory Response in Membranous Glomerulo-Nephritis Rat via Downregulation of NF$\kappa B$ Signaling Pathway. Kidney and Blood Pressure”, 2016.

[4] Takeuchi O, Akira S. "Pattern Recognition Receptors and Inflammation". Cell,2010.

[5] Cotran, R. S., Kumar, V., Collins, T., \& Robbins, S. L. "Robbins pathologic basis of disease. Philadelphia: Saunders",1999.

[6] Grivennikov, S.I., Greten, F.R., and M. Karin. . "Immunity, Inflammation, and Cancer.” Cell. vol 140(6):pp883-99, 2010.

[7] Kolb., H., and T. Mandrup-Poulsen. "The global diabetes epidemic as a consequence of lifestyle-induced low-grade inflammation.” Diabetologia. vol 53(1): pp10-20, 2010.

[8] Miller, A.H., Malteic, V., C.L. Raison. "Inflammation and its discontents: the role of cytokines in the pathophysiology of major depression." Biol Psychiatry. vol 65(9):pp732-41, 2009.

[9] Mallbris L, Akre O, Granath F, Yin L, Lindelöf B, Ekbom A, et al. "Increased risk for cardiovascular mortality in psoriasis inpatients but not in outpatients". Eur J Epidemiol pp19:225-30, 2004.

[10] Prodanovich S, Ma F, Taylor JR, Pezon C, Fasihi T, Kirsner RS. "Methotrexate reduces incidence of vascular diseases in veterans with psoriasis or rheumatoid arthritis". J Am Acad Dermatol Vol 52: pp262-7,2005

[11] O'Keefe JH, Gheewala NM, O'Keefe JO. "Dietary strategies for improving post-prandial glucose, lipids, inflammation, and cardiovascular health." J Am CollCardiol Vol 51: pp 249-255,2008

[12] Manohar V, Talpur NA, Echard BW, Lieberman S, Preuss HG. Jan 2002, "Effects of a water-soluble extract of maitake mushroom on circulating glucose/insulin concentrations in KK mice.", Diabetes ObesMetab.vol 4 (1): 43-8.

[13] Samantha J. Venable; Diane S. Aschenbrenner. "Drug Therapy In Nursing”. Hagerstown, MD: Lippincott Williams \& Wilkins. ISBN 0-78174839-9,2008

[14] Brunger, A. X-PLOR, Version 3.1: “A System for X-Ray Crystallography and NMR.” Yale University, New Haven, CT. 1992

[15] Grubmuller, H., H. Heller, A. Windemuth, \& K. Schulten. "Generalized Verlet algorithm for efficient molecular dynamics simulations with long-range interactions." Mol. Sim. 6:121-142,1991.

[16] Jorgensen, W. L., J. Chandresekhar, J. D. Madura, R. W. Impey, \& M. L.Klein. "Comparison of simple potential functions for simulating liquid water". J. Chem. Phys. vol 79 pp926-935,1983.

[17] Kale L, Skeel R, Bhandarkar M, Brunner R, Gursoy A, Krawetz N, Phillips J, hinozaki A, Varadarajan K, \&Schulten K NAMD2: “Greater scalability for parallel molecular dynamics". JComputPhys, 151:283,1999

[18] Laskoswki, R. A., MacArthur, M. W., Moss, D. S. \&Thorton, J. M. (1993). PROCHECK: "a program to check the stereochemical quality of protein structures". J. Appl. Cryst. vol 26, pp283-291,1993.

[19] MacKerell, Jr., Bashford A.D.D, Bellott M, Dunbrack R.L, Evanseck J, Field M. J, Fischer, Gao J, Guo H, Ha S, Joseph D, Kuchnir L, Kuczera K, Lau F. T. K, Mattos C, Michnick S , Ngo T, Nguyen D. T, Prodhom B, Roux B, Schlenkrich M, .Smith, Stote R,J. Straub, M. Watanabe, J. Wiorkiewicz- Kuczera, D. Yin, and M. Karplus. "Self-consistent parameterization of biomolecules for molecular modeling and condensed phase simulations". FASEB J.6:A143-A143,1992.

[20] Altschul, S. F., Gish, W., Miller, W., Myers, E. W. and Lipman, D. J. “A basic local alignment search tool” J. Mol. Biol.vol 215 pp $403-$ $410,1990$.

[21] Altschul, S. F., Madden, T. L., Schaffer, A., Zhang A, J., Zhang, Z., Miller.W, new generation of protein database search programs". Nucleic Acids Res vol. 50: pp 3389-3402,1997. 


\section{AUTHORS PROFILE}

C. Dhanunjaya Kumar MSc., SLET [ Ph.D ] at present is a senior research scholar in department of Biotechnology Sri Krishnadevaraya University Anantapuramu of Andhra Pradesh .He is university first ranker in post graduation. He received two gold medals. One from Sri Krishnadevaraya University and another one is from the Higher Education Department of Andhra Pradesh. In the year 2015 he warded with Prathiba award from state government of Andhra Pradesh. He qualified AP SLET exam for Assistant professor and as well as qualified Karnataka state government KSET exam. research topic since 2016.He is having 4 years experience in Biotechnology and Biochemistry PG classes in both the teaching and as well

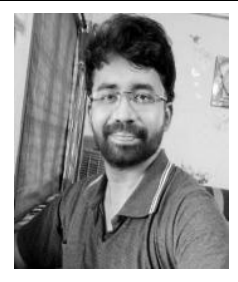
as research .He participated a number national seminars and presented the papers .He wrote a book on cancer and published in regional telugu language.

S.Nasireen Begum M.Tech,[ Ph.D] is persuing her Ph.D JNTU Anantapuramu .She did her M.tech in Biotechnology JNTU Anantapuramu. She is University topper in Mtech Biotechnology and winner of prestigious Prathiba award of Government of Andhra Pradesh .She worked as Junior research fellow in sri Vidyanikethan and as well as Assistant professor in the same college at Tirupati. She is having 3 years teaching and as well as research experience in the biosciences department.

D. Muralidhara Rao MSc., Mphil., NET., Ph.D is an eminent Professor in department of Biotechnology of Sri Krishnadeverya University, Ananatapuramu,Andhra Pradesh, He did his MSc in Sri Venkateswara University Tirupati of Andhra Pradesh ,India. He qualified CSIR NET and did his Ph.D in Sri Krishnadevaraya University .Later he did his Post Doc in veterinary sciences .He completed a number of projects .He selected as a panel and committee members by government for reputed scientific researches and as well as research boards. He is good researcher who published nearly more than 60 national and

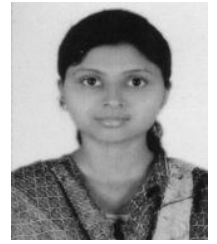
international Research papers in various reputed journals .He contains a patent right in the production of lysine from the Corynebacterium glutamicum and 3 more patents are applied.He worked as Head of Department to Biotechnology ,S.K.University and as well coordinator to department of Biotecnolgy JNTU ,Anantapuramu. He awarded 16 PhDs He is having 18 years experience in teaching. He is acting as as member to so many biological scientific committees.He is acting as a visting professor to a number of foreign Universities.He is a member of Biofertilizer production project committee at Department of Biotechnology ( DBT ) of India. 